\title{
Membangun Kompetensi Nelayan Dalam Industri Kelautan
}

\author{
I Gede Astra Wesnawa1, Putu Indra Christiawan ${ }^{1,}{ }^{*}$, Agus Sudarmawan ${ }^{2}$, Luh Gede \\ Erni Sulindawati ${ }^{3}$
}

1 Jurusan Pendidikan Geografi, Universitas Pendidikan Ganesha, Indonesia

${ }^{2}$ Jurusan Pendidikan Seni Rupa, Universitas Pendidikan Ganesha, Indonesia

${ }^{3}$ Jurusan D3 Akuntansi, Universitas Pendidikan Ganesha, Indonesia

\begin{abstract}
Abstrak
Pengembangan industri kelautan merupakan bagian integral dalam upaya pencapaian Indonesia sebagai poros maritim dunia. Nelayan sebagai ujung tombak pengembangan ini harus mengimbanginya dengan kompetensi yang baik. Akan tetapi, nelayan secara umum hanya memiliki kemampuan yang homogen, yaitu untuk melaut dan menangkap ikan. Permasalahan yang dihadapi nelayan dalam pengembangan industri kelautan, khususnya di Desa Sangsit adalah usaha yang dilaksanakan masih bersifat parsial dan individual. Berdasarkan permasalahan yang dihadapi nelayan tersebut, maka solusi yang ditawarkan dalam mengembangkan industri kelautan adalah secara kolektif-aktif serta berorientasi keuntungan ekologis dan ekonomis. Tujuan dari program ini adalah dengan mendorong tumbuhnya sikap, keterampilan dan motivasi nelayan dalam mengoptimalkan potensi dan peluang industri kelautan. Program kemitraan ini dilaksanakan dengan pola pelatihan dan pendampingan kepada nelayan sebagai mitra yang telah berhasil meningkatkan pengetahuan dan kemampuan mitra dalam usaha pembuatan perahu dan servis mesin perahu.
\end{abstract}

Keywords:

Kompetensi Nelayan;

Industri Kelautan;

Pembuatan Perahu;

Servis Mesin Perahu

\section{Pendahuluan}

Indonesia merupakan negara maritim terbesar di dunia dengan dua pertiga wilayahnya terdiri dari wilayah perairan. Indonesia sebagai negara kepulauan memiliki 18306 pulau yang dipersatukan oleh laut dengan panjang garis pantai $81.000 \mathrm{Km}$. Laut di Indonesia mempunyai potensi yang sangat besar. Potensi sumberdaya tersebut ada yang dapat diperbaharui (renewable resource) meliputi sumberdaya perikanan dan energi yang tidak dapat diperbaharui (non-renewable resources) meliputi sumberdaya minyak dan gas bumi serta mineral. Selain itu juga terdapat potensi sumberdaya kelautan lain, yaitu jasa lingkungan kelautan yang dapat dikembangkan untuk pembangunan ekonomi pesisir dan ekonomi kelautan nasional meliputi pariwisata bahari, industri kelautan, perdagangan, pelabuhan dan jasa angkutan (Trimulyono \& Santosa, 2014).

Colgan (2006) menyatakan bahwa perbedaan antara ekonomi pesisir (coastal economy) dan ekonomi lautan (ocean economy) yaitu ekonomi lautan didefenisikan sebagai aktivitas ekonomi yang secara langsung atau tak langsung memanfaatkan laut (danau besar) sebagai input. Sedangkan, ekonomi pesisir mendefinisikannya sebagai semua aktivitas yang berlangsung di wilayah pesisir. Colgan (2006) mengatakan bahwa ekonomi pesisir merupakan suatu pendekatan perluasan ekonomi geografis. Secara geografis sebagian besar ekonomi kelautan berada di wilayah pesisir dan sebagian bukan di wilayah pesisir termasuk salah satunya pembangunan perahu (boat) dan perdagangan makanan laut (Supriyanto, Santosa, \& Basukianto, 2016). Sedangkan ekonomi pesisir terdiri dari semua aktivitas ekonomi di wilayah pesisir, dengan kesempatan kerja penuh, upah hingga setiap output secara geografis dianggap sebagai ekonomi pesisir. Akibatnya, beberapa aktivitas ekonomi pesisir merupakan ekonomi kelautan. Akan tetapi, ekonomi pesisir menyatukan secara luas dari sekumpulan aktivitas ekonomi kelautan. Dengan kata lain, segala potensi sumberdaya pesisir dan pantai merupakan bagian besar dalam ekonomi kelautan (Mulyadi, 2005).

Pulau Bali sebagai bagian dari negara maritim Indonesia adalah wilayah kepulauan yang memiliki sumberdaya bahari yang sangat kaya dan berlimpah (biodiversity). Sumberdaya bahari ini terdiri dari keberlimpahan hasil tangkapan, keindahan terumbu karang, pantai yang eksotis dan berbagai kebermanfaatan dari hutan mangrove (Bengen, 2001). Masyarakat pesisir pada umunya dan masyarakat nelayan pada khususnya adalah masyarakat yang memiliki tingkat kesejahteraan yang tinggi (Widyastini

\footnotetext{
* Corresponding author.

E-mail Addresses: indra.christiawan@undiksha.ac.id (Putu Indra Christiawan)
} 
\& Dharmawan, 2013). Hal ini dikarenakan segmen masyarakat ini merupakan masyarakat dengan kehidupan dan penghidupan yang bersentuhan secara langsung dengan berbagai keberlimpahan sumberdaya hayati tersebut.

Kabupaten Buleleng merupakan wilayah dengan garis pantai terpanjang di Provinsi Bali, yaitu sepanjang $159 \mathrm{~km}$ (BPS Kab. Buleleng, 2015). Panjang garis pantai yang dimiliki secara tidak langsung menjadikan Kabupaten Buleleng sebagai wilayah dengan jumlah masyarakat pesisir terbesar di Provinsi Bali. Sebagai bagian dari Provinsi Bali, wilayah dan masyarakat pesisir di Kabupaten Buleleng tidak secara menyeluruh berorientasi pada pengembangan objek pariwisata. Sebagian besar kehidupan dan penghidupan masyarakat pesisir di Kabupaten Buleleng masih berbasis pada ekonomi kelautan. Meskipun sebagian besar masyarakat pesisir memiliki pekerjaan sebagai nelayan, tetapi daerah pantai Kabupaten Buleleng belum mengalami perkembangan pada sektor perikanan dan kelautan yang relevan dan signifikan. Kecamatan Sawan merupakan salah satu dari 9 kecamatan yang ada di Kabupaten Buleleng yang mempunyai luas wilayah $\pm 92,52 \mathrm{~km} 2$, terdiri dari 14 Desa dan 18 Desa Pakraman. Dilihat dari topografi wilayah, wilayah Kecamatan Sawan sebagian besar merupakan daerah pegunungan dan perbukitan dengan ketinggian 0 - 950 meter di atas permukaan laut dan sebagian kecil merupakan daerah dataran rendah dengan ketinggian 0-15 meter di atas permukaan laut. Adapun batas-batas wilayah Kecamatan Sawan adalah sebagai berikut. Berbatasan dengan Laut Bali di sebelah utara, berbatasan dengan Kecamatan Sukasada di sebelah selatan, Kecamatan Buleleng di sebelah barat dan berbatasan dengan Kecamatan Kubutambahan di sebelah timur (BPS Kec. Sawan, 2015).

Desa Sangsit merupakan salah satu desa yang secara administratif berada di Kecamatan Sawan, Kabupaten Buleleng. Desa Sangsit berbatasan langsung dengan Laut Bali di sebelah utara, berbatasan dengan Desa Giri Emas, Desa Bungkulan dan Desa Jagaraga di sebelah timur, berbatasan dengan Desa Suwug dan Desa Jagaraga di sebelah selatan dan berbatasan langsung dengan Desa Kerobokan dan Desa Sinabun di sebelah barat. Desa Sangsit terbagi menjadi 7 dusun/banjar yaitu Banjar Dinas Pabeansangsit, Beji, Celuk, Sema, Peken, Tegal, dan Banjar Dinas Abasan. Desa Sangsit memiliki luas 3,60 km2. Secara astronomis Desa Sangsit terletak pada posisi 0804'23” LS - 11507'15” BT - 11509'21" BT.

Berkenaan dengan potensi ekonomi, perekonomian Desa Sangsit sangat berkaitan dengan potensi kelautan. Hal ini terlihat dari jumlah sarana perikanan yang dimiliki. Sarana perikanan yang dimiliki di Desa Sangsit berupa keberadaan balai kelompok nelayan yang berjumlah 2 buah, memiliki satu-satunya tempat pelelangan ikan di Kecamatan Sawan, memiliki 19 buah perahu atau jukung dan memiliki 75 buah kapal motor tempel atau yang terbesar dari segi jumlah dibandingkan dengan desa pesisir lain di Kecamatan Sawan. Keberadaan sarana perikanan tersebut tidak hanya digunakan untuk aktivitas melaut, tetapi juga secara konsisten mengikuti perlombaan perahu layar di Kabupaten Buleleng dalam rangka HUT RI seperti terlihat pada Gambar 1. Pada penyelenggaraan lomba tahun 2014 kelompok nelayan Satria Samudra dari Desa Sangsit menjadi juara ketiga. Berbasis dari profil potensi geografis dan sumberdaya manusia, termasuk sumberdaya buatan dalam wujud sarana perikanan yang terdapat di Desa Sangsit, maka pengembangan yang paling sesuai dan prospektif untuk memberdayakan masyarakat nelayan adalah dengan mengembangkan industri kelautan di Desa Sangsit, selai sebagai sentra perikanan, dapat juga dikembangkan industri jasa pembuatan perahu nelayan dan jasa servis mesin perahu.

Adapun permasalahan-permasalahan yang dihadapi oleh masyarakat Desa Sangsit, khususnya masyarakat pesisir secara garis besar, terutama dalam bidang industri jasa yang meliputi pembuatan perahu dan perbaikan mesin adalah usaha yang ada masih berjalan secara parsial, sehingga belum mendapatkan hasil yang optimal dan tidak merata, dan juga masih bersifat individual, sehingga industri kelautan yang ada belum dapat dieksplorasi secara luas, dan hanya dikenal oleh masyarakat lokal. Berbasis dari berbagai prospek dan permasalahan yang telah diuraikan, maka adapun fokus bidang garapan (kluster) yang dibutuhkan oleh desa untuk segera mendapatkan pemecahan adalah kluster pengembangan sumberdaya manusia melalui pelatihan dan pendampingan untuk meningkatkan keterampilan industri jasa kelautan di Desa Sangsit.

\section{Metode}

Metode pelaksanaan program yang digunakan adalah model Partisipatory Rural Appraisal (PRA), model Entrepreneurship Capacity Building (ECB), model Technology Transfer (TT) dan menerapkan Teknologi Tepat Guna (TTG). Indentifikasi masalah menggunakan model Partisipatory Rural Appraisal (PRA) PRA adalah suatu teknik untuk menyusun dan mengembangkan program operasional dalam pembangunan tingkat desa (Chambers, 1996). Metode ini ditempuh dengan memobilisasi sumberdaya manusia dan alam setempat, serta lembaga lokal guna mempercepat peningkatan produktivitas, menstabilkan, dan meningkatkan pendapatan masyarakat serta mampu pula melestarikan sumberdaya setempat. Bertolak dari konsep PRA, maka tahapan kegiatan dalam model ini adalah melaksanakan identifikasi masalah setiap kluster, baik kluster bidang regulasi adat dalam bentuk awig-awig, bidang 
industri jasa kelautan dan sarana promosi maupun bidang pendidikan lingkungan, dan juga dalam perumusan program dan pendanaan program dilakukan secara terarah dengan berpihak dan senantiasa melibatkan masyarakat. Dengan demikian dalam merumuskan masalah, mengatasi masalah, penentuan proses dan kriteria masalah harus selalu mengikutsertakan, dan bahkan ditentukan oleh masyarakat/kelompok sasaran, yaitu masyarakat nelayan.

Penggunaan model pendekatan di atas diharapkan akan: (1) dikenalnya masalah secara tepat atau efektif sesuai dengan pesepsi, kehendak, dan ukuran atau kemampuan serta kebutuhan kelompok sasaran, (2) tumbuhnya kekuatan (empowering) masyarakat atau kelompok sasaran dalam pengalaman merancang, melaksanakan, mengelola dan mempertanggungjawabkan upaya peningkatan atau pertumbuhan diri dan kondisi ekonomi mereka, dan (3) efektif dan efisiens dalam penggunaan sumberdaya masyarakat atau kelompok sasaran. Selanjutnya melalui analisis dengan model PRA ini akan dapat dinventarisir berbagai keterbatasan dan keterpenuhan berbagai sumberdaya, sarana dan prasarana maupun jenis-jenis usaha masyarakat nelayan di Desa Sangsit. Di samping itu, akan ditemukan berbagai jenis kesenjangan dan kemiskinan secara mendalam baik secara natural, struktural, ataupun kultural. Berdasarkan identifikasi masalah akan dirancang berbagai perencanaan profil wilayah berupa program aksi. Rencana program aksi sebelum disosialisasikan kepada masyarakat atau kelompok sasaran, terlebih dahulu dikonsultasikan dengan Kepala Camat dan Kepala Desa untuk kemudian memperoleh tanggapan, umpan balik maupun masukkan dari masyarakat atau kelompok sasaran yang akan digunakan sebagai bahan revisi dari rancangan program aksi.

Pelaksanaan program dengan model Entrepreneurship Capacity Building (ECB) dan model Technology Transfer (TT) serta menerapkan Teknologi Tepat Guna (TTG) yaitu Model ECB terkait erat dengan kemampuan berwirausaha dari masyarakat (Hardjanto, 2006), dengan model ini diharapkan: (1) memberikan wawasan, sikap, dan keterampilan usaha, (2) memberikan peluang, (3) memfasilitasi peralatan serta (4) memonitor dan mengevaluasi tingkat perkembangan usaha mereka. Model TT dilakukan agar kelompok sasaran: (1) dapat menguasai prinsip-prinsip penerapan teknologi terutama yang berkaitan dengan industri jasa kelautan yang sedang atau yang akan dilaksanakan, (2) apabila teknologi yang diterapkan dirasakan terlalu rumit untuk menyelesaikan masalah yang dihadapi atau kebutuhan yang ingin dipenuhi, maka ketua program P2M memiliki kewajiban untuk menyederhanakan melalui penerapan TTG dengan menghasilkan replika atau modifikasi teknologi dengan alat sederhana yang dapat menyelesaikan masalah. Sasaran dalam pelaksanaan kegiatan ini adalah masyarakat pesisir di Desa Sangsit, khususnya masyarakat nelayan yang tersebar di Banjar Pabean Sangsit sebagai wilayah yang berbatasan langsung dengan laut dan paling banyak terdapat permukiman nelayan. Terdapat 2 kelompok yang masing-masing terdiri dari 10 mitra untuk mengikuti kegiatan pelatihan dan pendampingan industri kelautan.

\section{Hasil dan Pembahasan}

Pelaksanaan program kemitraan dilaksanakan dengan kegiatan pelatihan yang memberikan pengetahuan tentang bentuk-bentuk industri kelautan, serta kegiatan pendampingan untuk memberikan bimbingan teknis untuk mencapai keterampilan nelayan dalam mengembangkan industri kelautan dalam bentuk jasa pembuatan dan perbaikan perahu serta jasa perawatan dan perbaikan mesin perahu.

Upaya membangun pemahaman nelayan tentang industri kelautan dilaksanakan dalam bentuk kegiatan pelatihan. Kegiatan pelatihan dalam program kemitraan ini merupakan kegiatan transfer pengetahuan dan pengalaman narasumber yang telah lama berkecimpung dalam industri kelautan. Kedua narasumber adalah masyarakat nelayan di Desa Sangsit yang memiliki pekerjaan samping di kedua industri jasa tersebut.

Pelatihan Jasa Pembuatan dan Perbaikan Perahu dapat dijabarkan sebagai berikut. Kegiatan pelatihan pertama ini memfokuskan pada industri jasa pembuatan dan perbaikan perahu nelayan dengan mempresentasikan tentang tahap persiapan, tahap pembuatan dan evaluasi pembuatan perahu. Kegiatan pelatihan ini berjalan dengan baik dan lancar. Kondisi ini dikarenakan mitra sangat antusias dan memberikan respon yang cepat terhadap materi pelatihan yang disampaikan oleh narasumber. Hal ini dikarenakan seluruh mitra memiliki perahu, dan secara tidak langsung mendapatkan pengetahuan tentang langkah-langkah pembuatan dan perbaikan perahu yang baik dan benar. Antusias mitra terlihat terutama ketika narasumber membahas dan mendiskusikan tentang persiapan berbagai alat yang akan dipergunakan dan masing-masing fungsi alat dan perlengkapan.

Narasumber juga menjelaskan secara lengkap tahapan pembuatan perahu tersebut. Adapun penjelasan tahapan pembuatan perahu nelayan adalah sebagai berikut. Pertama, persiapan kayu konstruksi. Papan-papan kayu (dipergunakan kayu jati atau kayu besi) dengan ketebalan sekitar $4-5 \mathrm{~cm}$ yang telah dikumpulkan untuk membentuk dinding perahu. Selain itu, dipersiapkan juga balok-balok kayu dengan berbagai ukuran untuk konstruksi bagian dalam perahu. Dalam tahap ini pekerjaan yang utama 
adalah pembentukan pelat yang dilakukan dengan pembersihan, penandaan, pemotongan dan lain sebagainya. Kedua, pembuatan papan-papan lengkung.

Papan kayu yang tidak digergaji dibentuk atau dilengkungkan dengan cara memanaskannya melalui tungku khusus. Pada waktu papan kayu dipanaskan dengan suhu tertentu, kedua ujungnya diberikan pemberat sehingga sedikit demi sedikit papan tersebut akan melngkung. Dalam proses pelengkungan tersebut, papan kayu disiram dengan air pada saat-saat tertentu agar kayu tidak terbakar. Pemanasan memerlukan waktu sekitar setengah sampai tiga perempat jam, tergantung pada kondisi papan kayu yang dilengkungkan, dan ukuran perahu yang dibuat. Ketiga, pembuatan lunas (bagian bawah) perahu. Pembuatan lunas merupakan bagian yang terpenting dari sebuah perahu karena bagian ini adalah bagian yang rawan terhadap kebocoran. Lunas perahu dibuat dengan mempergunakan kayu jati berukuran sekitar $1-20 \mathrm{~cm}$ dengan ukuran panjang sesuai dengan kebutuhan dan,atau permintaan. Setelah proses tersebut, maka dibuat ujung perahu untuk disatukan dengan lunas perahu. Keempat, tahap perakitan. Konstruksi dalam seperti kerangka geladak atau dasar biasanya dirakit tersendiri lebih dahulu dalam tahap perakitan mula atau awal. Dalam tahap ini biasanya dilakukan proses penyambungan atau pengeleman. Kelima, tahap finishing. Tahap akhir adalah penghalusan konstruksi perahu, terutam pada badan perahu yang akan dicat.

Pelatihan Jasa Perawatan dan Perbaikan Mesin Perahu

Kegiatan pelatihan kedua memfokuskan pada industri jasa perawatan dan perbaikan mesin perahu dengan mempresentasikan tentang pengertian dan tujuan perawatan mesin, jenis perawatan, teknik perawatan dan perbaikan mesin perahu. Kegiatan pelatihan ini berjalan dengan baik dan lancar. Kondisi ini dikarenakan mitra sangat antusias dan memberikan respon yang cepat terhadap materi pelatihan yang disampaikan oleh narasumber. Hal ini dikarenakan seluruh mitra pernah mengalami berbagai gangguan pada mesin perahu, dan merasakan dampak negatif dari kerusakan mesin perahu, terutama saat melaut. Antusias mitra terlihat terutama ketika narasumber membahas dan mendiskusikan tentang berbagai jenis gangguan pada mesin dan cara mengatasinya.

Pada umumnya gangguan pada motor-motor bensin, disebabkan oleh kurang tepatnya pengaturan sistem bahan bakar, pengapian serta kompresi dalam ruang pembakaran. Gangguan motor dapat digolongkan dalam 4 (empat) macam yakni: (1) motor sukar hidup dan tidak mampu hidup sama sekali, (2) motor hidup tetapi tidak sempurna, (3) motor mati mendadak dan disertai suara keras dan (4) motor hidup tetapi ada kebocoran.

\section{Memperkuat Kompetensi Nelayan dalam Industri Kelautan}

Upaya memperkuat kompetensi nelayan tentang industri kelautan, maka dilaksanakan kegiatan pendampingan. Kegiatan pendampingan pada dasarnya memberikan bimbingan secara teknis untuk menindak-lanjuti pemahaman tentang materi yang telah disampaikan pada saat kegiatan pelatihan. Kegiatan pendampingan pada kedua jenis industri tersebut masing-masing dilaksanakan selama 3 hari. Secara teknis kegiatan pendampingan pada hari pertama akan diberikan penerapan langsung oleh para narasumber, pada hari kedua mitra menerapkan tahapan kegiatan industri secara kolektif dan pada hari ketiga mitra menerapkan tahapan kegiatan secara mandiri.

Kegiatan Pendampingan Jasa Pembuatan dan Perbaikan Perahu

Kegiatan pendampingan pada hari pertama diawali dengan persiapan berbagai alat dan bahan yang diperlukan untuk membuat dan memperbaiki perahu, kemudian narasumber mendemonstrasikan proses pengerjaan. Kegiatan pendampingan pertama ini mendemonstrasikan proses pembuatan perahu, terutama pada tahap perakitan. Hal ini dikarenakan tahap perakitan merupakan tahap pembuatan kapal yang sangat rentan kesalahan, terutama pada proses pembuatan tempat pasak dan penyambungan badan perahu. Kegiatan pendampingan pada hari kedua mengutamakan kerja-sama kelompok dalam bekerja. Kerja-sama kelompok sangat diperlukan, terutama dalam merakit bagian-bagian perahu menjadi satu. Hal ini dikarenakan beban dari badan perahu relatif berat, dan harus dikerjakan secara bersama. Kegiatan pendampingan pada hari ketiga dilaksanakan untuk menilai keterampilan kerja mitra secara individu. Keterampilan individu diperlukan khususnya dalam tahap persiapan untuk membentuk pelat atau badan perahu. Keterampilan dari setiap nelayan dimaksudkan untuk memperlancar pembagian kerja kelompok dan mempercepat masa pengerjaan pembuatan perahu.

Adapun kendala yang dihadapi nelayan dalam proses pembuatan perahu terutama dalam perakitan badan perahu. Seringkali badan yang dirakitkan belum terpasang secara simetris. Melihat kendala tersebut, narasumber dan tim pelaksana turun langsung untuk mendampingi mitra dalam memperbaiki posisi badan perahu untuk dirakit ulang sesuai dengan instruksi narasumber. Adapun kendala dan antisipasi dalam kegiatan pendampingan seperti terlihat pada Tabel 1.

Tabel 1. Kendala dan Antisipasi Pembuatan dan Perbaikan Perahu 


\begin{tabular}{clll}
\hline No & \multicolumn{2}{c}{ Kendala } & \multicolumn{1}{c}{ Antisipasi } \\
\hline $\mathbf{1}$ & $\begin{array}{l}\text { Kesalahan pada pembuatan dan } \\
\text { pemasangan ujung perahu, }\end{array}$ & Pengukuran harus dilakukan dengan teliti, dan dipasang \\
& $\begin{array}{l}\text { sehingga ujung pengahu tidak } \\
\text { menempel sempurna (dengan rata) }\end{array}$ & \\
$\mathbf{2}$ & $\begin{array}{l}\text { Pengecatan badan perahu yang } \\
\text { belum halus }\end{array}$ & $\begin{array}{l}\text { Harus didempul sampai merata dan halus, baru kemudian } \\
\text { dicat }\end{array}$ \\
$\mathbf{3}$ & Cat perahu cepat pudar & Setelah cat kering, maka perahu ditutup dengan daun kelapa \\
$\mathbf{4}$ & Bagian bawah perahu cepat rusak & Perahu yang sudah jadi ditambatkan pada pasir yang kering \\
\hline
\end{tabular}

\section{Kegiatan Pendampingan Jasa Perawatan dan Perbaikan Mesin Perahu}

Kegiatan pendampingan pada hari pertama ini diawali dengan persiapan berbagai alat dan bahan yang diperlukan untuk merawat dan memperbaiki mesin perahu. Kegiatan pendampingan pertama ini narasumber mendemonstrasikan proses perwatan mesin motor, khususnya motor bensin. Hal ini dikarenakan gangguan pada mesin motor berdampak sangat fatal apabila tidak diantisipasi sejak dini, terutama ketika sudah berada di tengah laut. Perawatan mesin motor bensin harus dilakukan secara berkala, dan juga pada saat sebelum melaut. Kegiatan pendampingan pada hari kedua mengutamakan kerja-sama kelompok dalam bekerja. Kerja-sama kelompok sangat diperlukan, terutama dalam proses perbaikan dalam kasus motor tidak dapat hidup mesin perahu. Hal ini dikarenakan proses perbaikan mesin motor yang tidak dapat hidup sangat kompleks, dari mengencangkan busi, mengganti piston hingga membersihkan katup. Kegiatan pendampingan pada hari ketiga dilaksanakan untuk menilai keterampilan kerja mitra secara individu. Keterampilan individu diperlukan khususnya dalam kasus gangguan pada sistem pengapian. Keterampilan dari setiap nelayan dimaksudkan untuk memperlancar pembagian kerja kelompok dan mempercepat masa pengerjaan perbaikan mesin perahu. Tabel 2.

Adapun kendala yang dihadapi nelayan dalam proses perbaikan mesin perahu seperti terlihat pada

Tabel 2. Kendala dan Antisipasi Perawatan dan Perbaikan MesinPerahu

\begin{tabular}{|c|c|c|}
\hline No & Kendala & Antisipasi \\
\hline 1 & $\begin{array}{l}\text { Kondisi busi tidak } \\
\text { sehingga tidak ada loncatan } \\
\text { bunga api pada busi }\end{array}$ & Membersihkan busi dengan cermat dan menyeluruh \\
\hline 2 & $\begin{array}{l}\text { Kesalahan pada pemasangan } \\
\text { busi, sehingga mengakibatkan } \\
\text { kompresi menjadi rendah }\end{array}$ & $\begin{array}{l}\text { Pemasangan baut harus dilakukan dengan teliti, dan dipasang } \\
\text { kencang }\end{array}$ \\
\hline 3 & $\begin{array}{l}\text { Bahan bakar yang dimasukkan } \\
\text { terlalu banyak, sehingga } \\
\text { karburator banjir bensin }\end{array}$ & $\begin{array}{l}\text { Bensin yang dimasukkan harus secara hati-hati, dan } \\
\text { memantau daya tampung }\end{array}$ \\
\hline
\end{tabular}

\section{Simpulan dan Saran}

Kegiatan pelatihan ini telah berhasil memberi wawasan tentang industri kelautan serta motivasi kepada nelayan untuk berwirausaha di wilayah pesisir Desa Sangsit. Pelatihan ini juga berhasil memberi kemampuan mitra untuk mengidentifikasi berbagai permasalahan dalam industri jasa kelautan dan upaya antisipasi secara praktis. Tanggapan mitra terhadap pelaksanaan kegiatan pembinaan dan pelatihan ini sangat baik. Hal ini dapat dilihat dari kehadiran peserta mencapai $100 \%$ dari target, dan selama kegiatan berlangsung mitra sangat antusias dan proaktif mengikuti kegiatan ini.

Berdasarkan pada kegiatan pelatihan dan pendampingan yang telah dilaksanakan kepada nelayan di Desa Sangsit. Dibutuhkan pelatihan dan pendampingan yang bersifat kontinu dan intensif dari berbagai pihak, termasuk pemerintah, khususnya di wilayah pesisir Desa Sangsit, dan juga desa-desa pesisir lainnya di Kecamatan Sawan yang mayoritas penduduknya memiliki mata pencaharian sebagai nelayan. Masyarakat pesisir, khususnya nelayan sangat membutuhkan informasi yang berkaitan dengan konsep dan pemahaman tentang industri kelautan serta keterampilan dalam mengelola potensi kelautan secara mandiri.

\section{Daftar Pustaka}


Badan Pusat Statistik Kabupaten Buleleng. (2015). Kabupaten Buleleng Dalam Angka Tahun 2015.

Badan Pusat Statistik Kecamatan Sawan. (2015). Kecamatan Sawan Dalam Angka Tahun 2015.

Bengen, D. G. (2001). Ekosistem dan Sumber Daya Alam Pesisir dan Lautan Secara Terpadu. Jakarta: PT Pramadya Pramita.

Chambers, R. (1996). PRA (Participatory Rural Appraisal) Memahami Desa Secara Partisipatif. Yogyakarta: Kanisius.

Colgan, C. S. (2006). Employment and wages for U.S Ocean and Coastal Economy. Monthly Labor Review.

Hardjanto, I. (2006). Pembangunan Kapasitas Lokal (Local Capacity Building). Malang: Program Pascasarjana Universitas Brawijaya.

Mulyadi, S. (2005). Ekonomi Kelautan. Jakarta: PT Raja Grafindo Persada.

Supriyanto, A., Santosa, A. B., \& Basukianto. (2016). Pengembangan usaha berbahan kain limbah dan velboa di kota semarang. Abdimas, 20(1), 1-10.

Trimulyono, A., \& Santosa, A. W. B. (2014). Pemberdayaan Masyarakat Pesisir Di Kabupaten Batang Jawa Tengah Melalui Pengembangan Industri Galangan Kapal Tradisional. Kapal, 11(1), 33-39.

Widyastini, T., \& Dharmawan, A. H. (2013). Efektivitas Awig-Awig dalam Pengaturan Kehidupan Masyarakat Nelayan di Pantai Kedonganan Bali. Jurnal Sosiologi Pedesaan, 1(1), 37-51. 